\title{
LAKI Gábor
}

\section{A FENNTARTHATÓ (ÉS MULTIFUNKCIONÁLIS) MEZŐGAZDASÁG HATÉKONYSÁGMÉRÉSI PROBLÉMÁI}

A szerző dolgozatában a fenntartható mezőgazdaság hatékonyságmérési kérdéseivel foglalkozik. Ebben a témában egy rendkívül szerteágazó, túlburjánzó szakirodalmi háttér áll a kutatók rendelkezésére, ugyanakkor a legtöbb szerző írásában csak általánosságokat, jövőbeni elképzeléseket, illetve gyakran egymásnak ellentmondó elveket ismételget, amelyek konkrét megvalósítására csupán kevés esély látszik. E kérdés problémáinak feloldására olyan integrált mutatószám bevezetése lenne célszerű, amely egyfelől egyszerű, így könnyen kezelhető, másfelől ,integráltságából” eredően, változása az egész gazdaság a fenntarthatóság irányába történő egyidejű elmozdulását eredményezi.

A fenntartható mezőgazdaság gyakorlati értelmezése, illetve a mezőgazdaság szerepe a vidéki térségek fenntartásában újra és újra vitatott kérdések a szakemberek körében. Ez annak a következménye, hogy eltérő álláspontok léteznek a fenntarthatóság fogalmának meghatározásában, amiből az is következik, hogy a mezőgazdaság és a vidéki térségek kapcsolata sem tisztázott még egyértelműen. Ennek eredményeképpen bár sokat emlegetik az integrált megközelítés szükségességét, mégis külön léteznek, egymással gyakran ellentétes eredményekre vezető politikák (pl. agrárpolitika, agrárkörnyezetvédelmi politika, vidékfejlesztési politika stb.), amelyek közül egyesek csak azért szükségesek, hogy megkíséreljék helyrehozni egy másik politika által kiváltott káros hatásokat. Másfelől, az elmúlt két évtizedben megjelent szakirodalmi források száma szinte megbecsülhetetlenné vált, mivel a fenntartható fejlődés és az agrárágazat fenntarthatósága annyira felkapott témákká váltak, hogy minden tudományterület művelője szinte kötelességszerűen ír róluk.

A valóban integrált megközelítés segíthet tisztázni: hogyan értelmezhető a mezőgazdaság fenntarthatósága, melyek azok a feladatok (funkciók), amelyeket meg kell őrizni ahhoz, hogy a mezőgazdaság kielégítse a fenntarthatóság általános definíciójának megfelelő követelményeket, valamint milyen erőforrásokat, milyen meny- nyiségben és minőségben kell megőrizni ahhoz, hogy a mezőgazdaság ezzel hozzájáruljon a vidéki térségek fejlődéséhez? A fenntartható mezőgazdaság gyakorlati céljainak leginkább megfelelő mezőgazdasági politikák és az ezekkel összhangban múködő gazdálkodási módok lassú kialakításának legfőbb oka az, hogy a jelenlegi agrártámogatási rendszerek mind Európában, mind hazánkban bár csökkenő tendenciával, de még mindig termelési funkciókhoz kötöttek. Külön problémát jelent az, hogy a jelenleg használt mutatószámok nem adnak reális képet a fenntartható mezőgazdaság kritériumainak megfelelő gazdálkodási módok hatékonyságáról, illetve összetettségükből kifolyólag lehetetlen a gazdaság szintű adatgyüjtés és feldolgozás. E problémák feloldására olyan integrált mutatószám bevezetése lenne célszerü, amely egyfelől egyszerű, így könnyen kezelhető, másfelől „,integráltságából” eredően, változása az egész gazdaság a fenntarthatóság irányába történő egyidejű elmozdulását eredményezi.

\section{A fenntartható mezőgazdaság hatékonyságmérésének rendszerelméleti alapjai}

Ha a mezőgazdaság fenntarthatóságát nem a fenntarthatóság három (gazdasági, társadalmi, környezeti) dimenziójának oldaláról vizsgáljuk (vagyis azt, hogy 
az adott gazdaság vagy gazdálkodási módszer gazdaságilag mennyire hatékony, mennyire környezetbarát stb.), hanem a vidéki térségek fejlődéséhez való hozzájárulást vesszük alapul, akkor a hangsúlyt a vidék (ahol a mezőgazdasági tevékenység is folyik) adott erőforráskészletének számbavételére kell helyezni. Ennek különösen az ad nagy jelentőséget, hogy az évszázadok alatt megváltozott város-vidék viszonyban csak a városi térségekkel versenyképes vidéki térségek maradhatnak fent, míg a városi igényekhez „fejlesztett” térségek (romantikus kirándulóhelyek, „múzeum falvak") fenntartása gazdaságilag már más probléma, mint eredetileg a mezőgazdaság fenntarthatósága. Bár kulturális értelemben minden ilyen település az adott állam kultúrájának szerves részét képezi, senki sem kényszeríthető a városi emberek számára elfogadhatatlan (pl. téli több kilométeres séták az autóbuszhoz) életfeltételek elviselésére. Indokolatlan továbbá azon térségek fenntartása és fejlesztése (pl. tanyavillamosítás) is, ahol amúgy sem él nagyszámú, önállóan életképes lakosság, ugyanis vonzóerő hiányában (az őlakosok kihalásával) e települések eltünése csupán idő kérdése. E településeknek a felszámolása, a lakosok nagyobb települések vonzáskörzetébe történő átköltöztetése társadalmi szinte még mindig „olcsóbban”, egyszeri „veszteségként megélve” oldható meg, mint hosszú távon abban bízni, hogy „majd csak ide jön valaki”. (Nem lehet komoly az a fejlesztési szándék, amely a helyi lakosokat poros úttal rendelkező, az infrastruktúrától távol eső tanyán akarja tartani!)

A vidéki térségek versenyképességének növelése csak saját természeti és emberi erőforráskészletük maximális kihasználásán keresztül valósítható meg. A külső erőforrásokra (pl. ipari eszközök, technológiák, szakismeret) alapozott fejlesztések, illetve a városi életmódhoz közelítő vidéki életszínvonal kialakítása nem növelik a vidéki versenyképességet, hanem csak konzerválják, illetve növelik a városoktól való függőséget. Minden előzetes empirikus vizsgálat nélkül belátható, hogy sosem lehet egyazon költségen ugyanazt a színvonalú szolgáltatást nyújtani vidéken, mint a városban. A vidéki térségek városi életmód szerint fenntartása, ellátása csupán nagyobb tranzakciós költségekkel valósítható meg, s az így fejlesztett vidék csupán „,ritkán lakott városokként" lenne jellemezhető.

A vidéki térségek definiálása egyben meghatározza a rendelkezésre álló erőforráskészlet körét és összetételét is. Ebből kiindulva, maga a „vidék” egyrészt egy adott helyen meglévo" természeti, emberi és ember alkotta erőforrások (épített környezet, életforma, kulturális értékek, szokások stb.) szervesen integrált rendszere, másrészt a mezögazdasági és egyéb gazdasági, valamint nem gazdasági emberi tevékenységek, továbbá a környezet-, a táj-és természetgazdálkodás szervesen integrált rendszere.

Ha az átfogó alaprendszernek a vidéki térséget tekintjük, akkor a mezőgazdaság ennek alrendszere, amely ebből következőleg csak integrált és multifunkcionális lehet, amely megfelel az „,európai mezőgazdasági modellnek" és amelynek a hatékony, versenyképes termelés mellett számos más feladata is van. Ez a vidék meghatározás segít tisztázni a mezőgazdaság és a vidék sokat vitatott kapcsolatait. Ha a mezőgazdaság a vidéki rendszer része, akkor természetszerü, hogy életképes vidék nem létezhet életképes mezőgazdaság nélkül, de ugyanakkor túlzott elvárások sem támaszthatók a mezőgazdasággal szemben. Lényeges továbbá, hogy a vidéki térségekben müködő egyéb tevékenységek is csak akkor tekinthetők a vidéki rendszer részének, ha magukon viselik a vidéki jelleget, szoros kapcsolatban vannak a vidéki rendszer többi alrendszerével, hozzájárulnak az egész zavarmentes fejlődéséhez, és nem rombolják annak struktúráját. Az életképes vidéki térségek versenyképességének növeléséhez legelőször el kell szakadni az évszázados specializáció okozta szemléletmódtól, vagyis a mezőgazdaság tevékenységi köreit nem a vidéki térségektől távolabb elhelyezkedő ipari létesítmények piackutatásainak alapján kell definiálni, hanem az adott erőforráskészlethez kell a megfelelő funkciókat hozzárendelni.

A mezőgazdaság funkcióinak újraértelmezésével megteremthető az agrárágazat európai szintű stabilitása is, amelynek jövője és alkupozíciójának pozitív irányú megváltozása a működési környezetét jelentő vidéki térségek fennmaradásától függ. A mezőgazdaság és a környezete, illetve a működési terét jelentő vidéki térségek között meglévő kapcsolatok fejlődési irányát ugyanakkor az agrárpolitika határozza meg. Mindezen összefüggések alapján megállapítható, az új, fenntartható európai mezőgazdaság modelljének gyakorlati megvalósítása attól is függ, vajon sikerül-e megalkotni a mezőgazdaság fenntarthatóságának valódi mérőszámrendszerét. Ennek hiányában az egyetlen társadalmi optimum kritérium az ökonómiai hatékonyság marad, amely a mezőgazdasági termékszerkezet további szűküléséhez, a vidéki térségek leértékelődéséhez vezet. E problémát felismerve, korábban már több nemzetközi szervezet (pl. ENSZ, ECNE, EEA, OECD vagy az EU) komoly kutatásokat indított egyegy átfogó mérőszámrendszer kidolgozására. Ezek a mutatószámrendszerek gondolatmenetükben közösek, csupán ábrázolásmódjukban térnek el egymástól (pl. számszerűsítők, GIS térképi ábrázolásúak). Hibájuk, 
hogy egyfelől túlságosan is környezeti orientáltságúak, vagyis a fenntarthatósági dimenziók közül a gazdasági, illetve a társadalmi dimenziók szinte alig jelennek meg, másfelől pedig, bonyolultságukból következően a rendszeres, gazdaság szintű adatgyűjtést és feldolgozást egyáltalán nem képesek megoldani.

Ha fel akarjuk használni a korábbi eredményeket, a bonyolult mutatók helyett célszerűnek tűnik egy, a vállalkozások szintjén is könnyen megszerezhető adatokra épülő, integrált célparaméter kidolgozása, amelynek változtatása (növelése) egyidejűleg szolgálná a gazdálkodási rendszer, illetve az adott vállalkozás esetében a fenntarthatóság mindhárom dimenziójának pozitív irányú változását. Ezt csak egy olyan mutatóval lehet elérni, amely a rendszerek heurisztikus önszervezésének elvére épül, amely feltételezi, hogy a rendszernek legalább két szintje (pl. a mezőgazdaság fenntarthatósága egésze és az egyéni gazdaságok) szorosan kapcsolódik egymáshoz. Mivel ebben a szoros kapcsolatban a nagyszámú, dinamikusan változó környezeti feltételek és ezek hatásai pontosan sohasem mérhetők és nem is tárhatók fel, így az eddigi mutatószámok hiányosságai erre vezethetők vissza. A nagyszámú, leíró jellegű mutatószámok (pl. OECD mutatószámai) döntő többsége csupán az egyes paraméterek évről-évre történő változásának dokumentálására képes, konkrét megoldást nem ad. A nem mérhető környezeti feltételeket azonban a magasabb szintű (irányító) szerveződésnek úgy kell kialakítania, hogy az alacsonyabb szintű saját önálló, önkezdeményező és önfejlesztő tevékenysége segítségével a kívánt irányú (eredményre vezető) viselkedéssel reagáljon. Kétségtelen, hogy a nagy önállósággal rendelkező alacsonyabb szintű szervezetek magatartása számos hibát is eredményez, de a környezeti tényezők és az ún. ,integrált hatások” segítségével kiváltott és fenntartott aktivitásuk gyorsan rávezeti őket a helyes megoldásokra (vö.: heurisztikus keresés!). Az irányított szervezet nagyobb szabadságával csökkenthető az irányító szervezet bonyolultsága, következésképpen a fenntartásának és működtetésének költsége is. Ez esetben a fejlődés új cselekvési, megoldási alternatívák feltárását és megvalósítását jelenti, ahol az „új” természetszerűen előre nem tervezhető és nem ismert megoldásokat jelent (Szakál, 1992). A heurisztikus önszervezésen alapuló integrált mutató kidolgozása éppen azt a célt szolgálja, hogy egy paraméter változtatásával az egész rendszer tulajdonsága megváltozik, $\mathrm{s}$ az egyéni gazdaságok integrált mutató szerinti pozitív irányú fejődése a mezőgazdaság egészének a fenntarthatóság felé történő elmozdulását eredményezheti. E koncepció alapján került kidolgozásra az ún. helyben előállitott hozzáadott érték mutató.

\section{A helyben hozzáadott érték (HHÉ) mutató koncepciója}

Miután a magyar agrárközgazdászok többsége csupán a gazdasági fenntarthatóság szempontjait elemzi, a környezeti és a társadalmi szempontok munkáikban csupán áttételesen vagy egyáltalán nem jelennek meg. Ezt figyelembe véve, a választott mutató alapvetően gazdasági oldalról közelíti meg a fenntarthatóság mezőgazdasági értelmezését, amely így az agrárközgazdászok számára is elfogadható álláspontot tükröz. Maga a helyben hozzáadott érték mutató alkalmasnak tűnik a mezőgazdaság fenntarthatóságának, illetve a mezőgazdaság a vidéki térségek fejlődéséhez (versenyképességének visszaállításához) való hozzájárulásának mérésére, hiszen a hozzáadott érték összegének növeléséhez rendelt bármely kormányzati támogatás összegét csak az adott tevékenységek hatékonyságának növelésével lehet emelni. Vagyis, ha a javasolt mutatóhoz kormányzati támogatási rendszert rendelnénk és a támogatások szétosztását a megtermelt hozzáadott érték nagyságához igazítanák, a termelők érdekeltek lennének újabb és újabb, nagy hozzáadott értékű termékek előállításában (itt jelenik meg a heurisztikus keresés). Ez a folyamatos mezőgazdasági innováció a helyi erőforrások nagyobb mértékủ és nagyobb hatékonyságú felhasználását jelentené, ami egyidejűleg növelheti a társadalmi jólétet is. Noha a hozzáadott érték a jólétnek nem egy egzakt mutatója, ám szoros korreláció mutatható ki a hozzáadott érték és a jóllét növekedése között.

A választott mutató csupán formálisan, a megkülönböztetés miatt kapta a helyben elóállitott hozzáadott érték nevet, ugyanis ez az elnevezés arra utal, hogy az adott térségben múködő gazdaság(ok) által elóállított hozzáadott értéket tekintem mérőszámnak, amelynek számítása módja némileg különbözik az általánosságban vett hozzáadott érték számítási módjától.

Maga a hozzáadott érték fogalma már évtizedek óta ismert az ökonómiában, hiszen vállalati szinten a vállalatok, illetve az általuk végzett (rész)tevékenységeinek értéknövelését jellemző mutató. Az egyes termékek és szolgáltatások esetében a hozzáadott érték a bevétel, valamint a felhasznált anyagokra és szolgáltatásokra fordított kiadásainak értékkülönbözete. Számításánál a bevételek összegéből ki kell vonni az anyagi jellegű ráfordításoknál felmerült kiadásokat, a tartós eszközök elszámolt értékcsökkenését és a fizetett kamatokat. Vagyis azt az új (többlet) értéket jelenti, ami az adott vállalat tevékenysége következtében adódott hozzá a más vállalatok által már előzőleg létrehozott értékhez. 
A hozzáadott értéken alapuló mérés koncepciója annyira nem új keletű, hogy maga az Általános Forgalmi Adó (ÁFA) koncepciója is erre épül. Az ÁFA elnevezése a legtöbb idegen nyelvben „többletérték adó” (Mehrwertsteuer) vagy szó szerint hozzáadott érték adó (value added tax), ami kifejezi azt, hogy egy termék elő́lllításában közreműködő minden szereplő az általa létrehozott értéknövekmény arányában fizet adót.

Társadalmi szempontból külön ki kell emelni, hogy az egyes gazdaságok saját tevékenységi körük bővítésével (pl. agrár-környezetvédelmi szolgáltatások végzése) egyben növelik az általuk elóállított hozzáadott érték mennyiségét is. A tevékenységi körök bővítésének (pluriactivity) számos típusa ismert mind a nemzetközi (Winter et al., 2002), mind a hazai szakirodalomban. Az ún. „soktevékenységűség” megvalósítható:

Saját gazdaságon belül: a gazdasági és lakóépületek más irányú kihasználása, új termékek előállítása, szállítóeszközök hasznosítása stb. Ezen belül fontos terület a falusi turizmus.

Mezőgazdaságon kívül: bérmunka vállalása, bolt üzemeltetése, javítóműhely stb.

Más gazdaságban végzett munkákkal: saját eszközökkel végzett szolgáltatás, kézi munka.

Ezt figyelembe véve, a helyben hozzáadott érték számítása mellett célszerűnek tartom a gazdaságon kívüli kereseti lehetőségeket is vizsgálni, amely megmutatja, hogy a családi gazdaságok jövedelemszerkezete hogyan alakul és melyek azok a tevékenységi körök, amelyek hozzájárulnak egy gazdaság hozzáadott érték-elóállításához. Ilyen irányú vizsgálatokat hazánkban csupán kevesen végeztek, így ezek közül a legjelentősebb a Módos et. al (2001) által publikált tanulmányok. Vizsgálataik szerint a mezőgazdasági családok jövedelme (források szerint) a következőkből tevődik össze:

- saját mezőgazdasági tevékenység,

- mezőgazdasági melléktevékenységek,

- más, a gazdaság erőforrásaira épülő nem mezőgazdasági tevékenység,

- gazdaságon kívüli munkavállalás,

- pénztranszferek, nyugdíjak (pl. adó-visszatérítés, támogatások),

- befektetések, megtakarítások és

- a kapott bérleti díjak.

A hozzáadott érték növelésénél külön figyelmet érdemel a fenntarthatóság társadalmi dimenziójának szempontjából a jövedelmezöség vagy az újratermelhetőség problémája, amely egy családi gazdaság számára egyenlő az életképességgel. Egy jól jövedelmező, sok

Konferencia előadás és személyes közlés hozzáadott értéket eloállító vállalkozás képes önmagát újratermelni, így a benne dolgozók nem érzik annak kényszerét, hogy azt idő előtt feladják, s ez a többlet alapja lehet a későbbi befektetéseknek, fejlesztéseknek is. Mára már Európa-szerte egyre erősödő tendencia, hogy a gazdálkodás feltételeit olyan külső meghatározó erők alakítják, amelyek a kisebb családi gazdaságok tömeges tönkremenetelét idézik elő. Azonban úgy tűnik, a családi gazdaságok nagy része képes az új feltételekhez is rugalmasan alkalmazkodni és sokféle tevékenység bevezetésével megőrizni a családi gazdálkodás önállóságát, fennmaradását. Így biztosítják, hogy a mezőgazdasági tevékenység mennyiségi növelése nélkül, sőt csökkentésével is megfelelő jövedelemre tegyenek szert, a mezőgazdasági jellegű háztartások fennmaradnak, és ami fontos, helyben (vidéken) maradnak. Az európai gazdaságok mintegy 50\%-a ma már különböző mezőgazdaságon kívüli tevékenységgel is foglalkozik és részidejű gazdasággá vált (Kertész, 2004)². A folyamatos családi ,innovációval” nem csupán az újabb tevékenységek számát lehet növelni, hanem az így elő́llított hozzáadott érték nagyságát is.

A hozzáadott érték előállítása szorosan összefügg a gazdaság jövedelmezőségével, amelynek következtében célszerű megvizsgálni az egyes gazdaságok nettó és bruttó jövedelmének eszközértékre, munkaórára, valamint egységnyi földterületre vetített arányát, hasonlóan a gazdaságban előállított hozzáadott érték egységnyi területre vagy munkaórára eső arányát is. Ezt az indokolja, hogy a fajlagosan nagy hozzáadott érték előállítása nem jelenti természetszerūen a gazdaság fenntarthatóság mindhárom dimenziója szerinti fenntarthatóságát, legfőképpen nem a gazdasági életképességet! Példának vehetünk egy olyan 5 tehenes gazdaságot, amely külterjes legeltetéssel oldja meg az állatok takarmányozását. Ha a gazdaságban elóállított évi 4500 liter tejen literenként 50 Ft hozzáadott érték képzödik, ez a gazdaság éves szinten sem tud többet elöállítani, mint $225000 \mathrm{Ft}$, amely a gazdaság egyhavi müködési költségét sem fedezi.

A hozzáadott érték növelését nem csupán a vállalkozó folyamatos, heurisztikus alapokon megvalósított innovációi és a jövőbe vetett hite segíti elő, hanem ösztönzőleg hathat az újratermelhetőségének vagy eltartó képességének növelése is. A helyben előállított hozzáadott érték növelése szorosan összefügg az eltartó képességgel, amelyet a gazdaságtól függő személyek minimális jövedelemigényének (MinJ) (amely az adott állam minimálbérével lehet egyenlő) és a gazdaság által megtermelt összes jövedelem (ÖJ) arányával lehet szemléltetni. Ha az ÖJ > MinJ, akkor a

Szóbeli közlés 
gazdaság évenként elóállított jövedelme elegendő a családtagok minimális megélhetésének biztosítására így a tevékenység nagy valószínűséggel hosszú távon fennmarad. Ebben az esetben a megtermelt összjövedelem és a családtagok számával felszorzott minimális jövedelemigény különbözete $(\mathrm{P})$, egy olyan többletbevételt jelent, amelyből fedezhető az évenkénti tevékenységek által igénybe vett eszközök amortizációja (A), így az újratermelés képessége egyenlő a $\mathrm{P}$ és az $\mathrm{A}$ hányadosával. Ez a dimenzió nélküli hányados azt mutatja meg, hogy a többletjövedelem hányszoros eszközpótlást tesz lehetővé. A kapott érték reciproka az az időszak (év) hossza, amikor az előállított jövedelemből pótolni lehet az elhasználódott eszközöket. Ha ez az érték egynél kisebb, akkor a vállalkozás soha nem lesz képes eszközeinek megújítására.

\section{A helyben előállított hozzáadott érték (HHE) számításának módszere}

Az előzőekben már utaltam arra, hogy a HHÉ kiszámítása reális képet adhat arról, hogy mennyi új érték keletkezett magában a mezőgazdasági tevékenységben a természeti erőforrások és az emberi tevékenységek használatából, vagyis arról, hogy mennyivel járult hozzá a mezőgazdaság egy adott vidéki térségben élők eltartásához, megélhetéséhez. A több terméket és szolgáltatást előállító vállalatok egyes résztevékenységeire vonatkozóan a HHÉ pontos kimutatása nehéz, mivel vannak olyan kiadások, amelyek csak vállalati szinten jelentkeznek (pl. a hitelek kamatai), így azok nem rendelhetők egyértelmúen sem termékekhez, sem pedig ágazatokhoz.

Maga a HHÉ számítási módszerében gyökeresen különbözik a gyakorlati számviteli megközelítéstől. Az erőforrásokat az alapvetően pénzügyi szemléletű számvitel eredetük szerint (pl. a gazdaságban előállított vagy a piacon vásárolt) az ágazatok szintjén sokszor nem különbözteti meg, csupán egyes esetekben tesz különbséget (pl. saját termelésű és vásárolt takarmányok). Ennek értelmében a mezőgazdasági termelés és szolgáltatás tárgyévi értékét képes értékelni, amelyben a hozamot fó- és melléktermékeket, a nyújtott szolgáltatások értékét, illetve az állatok súlygyarapodását valamilyen számított (ún. „elszámoló”) árral szorozzák. Ezek a tételek ökonómiai megközelítésben az adott mezőgazdasági vállalkozás hozamai, vagyis az általuk megtermelt áruknak és végzett szolgáltatásoknak adott időszakra vonatkoztatott értéke, amelyek egyben a hozzáadott értékszámításban a bevételi oldalon kerülnek feltüntetésre.

A helyben hozzáadott értéken alapuló mérésnél a gazdaságban a saját előállítású inputokat pozitív értékként kell elszámolni, míg a gazdaságon kívülről származó inputokat és szolgáltatásokat negatív értékként kell figyelembe venni. Kétségtelen tény, hogy a módszer valamivel több munkát jelent a gazdaság év végi eredményének kimutatásakor, ám maguk a hagyományos számviteli módszerek is alkalmasak ezen új koncepció gyakorlatba történő átültetésére. A számítási módszer lényege az, hogy a gazdaságban az éves múködés során keletkező számlákat úgy kell ellátni azonosítókkal, hogy ne csupán az éves mérleg szerinti csoportosításban lehessen az eredményt megkapni, hanem a HHÉ számításához nélkülözhetetlen bontásban is. Ehhez viszont a kereskedelmi forgalomban ma kapható könyvelőprogramokat minimálisan ugyan, de módosítani kellene úgy, hogy képesek legyenek különbséget tenni a saját elóállítású és a nem a gazdaságban előállított anyagok és szolgáltatások számlái között. Példaként vehetjük egy gépjavitás számláját, amelyen külön kellene feltüntetni a beszerzett alkatrész és az elvégzett munkadij összegét. Amennyiben a javitási munkát külső szolgáltató (pl. szakszerviz) végezte el, akkor a teljes számlaérték kerül levonásra, de saját kivitelezésben végzett javitás esetén csupán az alkatrész ára kerül levonásra. Ez a probléma szorosan kapcsolódik a területi lehatároláshoz.

Egy (családi) gazdaság esetében a hozzáadott értéket az alábbi módon lehet kiszámítani:

Összegezni kell a gazdaság éves múködése során keletkező bevételeket és az ezen időszak alatt végzett tevékenységek során felmerülő költségtételeket az alábbi szempontok szerint:

Bevételeknek (B) tekintendő:

- a növényi-, állati- és egyéb termékek és szolgáltatások eladásából származó bruttó bevételek,

- a készletben lévő saját termelésű készletek növekedésének, az állatállomány létszámának és/vagy súlyában is jelentkező gyarapodásának értéke,

- a saját kivitelezésben létrehozott épületek, berendezések, gépek, eszközök, ültetvények, valamint az elvégzett tartós talajjavítások értéke, illetve a saját kivitelezésben végzett, értéknövelő javítások és felújítások értéke,

- a háztartásban felhasznált, a gazdaságból származó termékek értéke,

- a gazdaságban dolgozók számára természetben fizetett bérek értéke,

- a bérbe adott földekből, eszközökből származó bevételek,

- az értékesített termékekért, illetve környezeti szolgáltatás(ok)ért kapott termelői támogatások, közvetlen kifizetések,

- a biztosítóktól kapott térítések,

- a kölcsönadott pénzek, illetve a bankbetétek kamatai, az értékpapírok, valamint más vállalkozások- 
ban lévő befektetések után kapott osztalékok és részesedések,

- pályázatok, támogatások és egyéb ilyen jogcímen kapott vagy elnyert összegek,

- az adott gazdaságban élők nem mezőgazdasági tevékenységeiből származó, nem bérként kapott bevételei,

- a vagyontárgyak értékesítéséért kapott bevételek.

Levonandó tételnek $(\mathrm{K})$ tekintendő:

- azon anyag és anyag jellegú ráfordítások pénzértéke, amelyek az adott gazdaságon kívülről kerülnek be a termelésbe (így pl. vásárolt vetőmagvak, szaporítóanyagok, mútrágyák, vásárolt szerves trágyák, növényvédőszerek, üzem-, kenő- és fütőanyagok, alkatrészek, villamos energia, a vásárolt takarmányok, állatgyógyszerek, építési anyagok, vásárolt ipari anyagok stb.),

- a vásárolt állatokért adott kiadások (ugyanakkor a hagyományos számviteli elszámolásban az állomány értéknövekedését a bevételi oldalon tüntetik fel),

- a gépek, berendezések karbantartására, javításaira kifizetett összegek, valamint a vásárolt vagy külső szolgáltató által létesített állóeszközök értékcsökkenéseinek leírása,

- az épületek, építmények javítási-, fenntartási ráfordításai, a talajjavítások, valamint az évelő kultúrák fenntartási költségei és ezek értékcsökkenése,

- a társadalombiztosításnak teljesített kifizetések,

- a vállalkozással kapcsolatos kifizetett utazási és szállásköltségek,

- idegen szolgáltatásokra (pl. állatorvosi vagy szaktanácsadási költségek), bérleti díjakra történő kifizetések, érdekképviseleti szerveknek, kamaráknak fizetett tagdíjak,

- biztosítási költségek,

- bankhitelek és egyéb kölcsönök fizetett kamatai,

- az adók és illetékek (ide értve a földadót és a személyi jövedelemadót is),

- az értékesített vagyontárgyak nettó értéke,

- az idegen által végzett beruházások és nagyobb javítások összes költsége,

- a kereskedelmi céllal, eladásra beszerzett áruk értéke, és az alvállalkozói teljesítésekre kifizetett öszszegek.

A gazdaság szintjén az így összesített tételek alapján már kiszámítható a helyben hozzáadott érték, hiszen értéke egyenlő a pozitív és a negatív tételek különbözetével, vagyis:

$$
\mathrm{HHÉ}=\mathrm{B}-\mathrm{K}
$$

A HHÉ a vállalkozások szintjén könnyen megszerezhető adatokra épülő, olyan integrált célparaméternek tűnik, amelynek - éppen az „integráltságából” fakadóan - növelése egyidejűleg növeli az egész gazdaság jövedelmező- és újratermelő képességét, illetve az egész gazdálkodásnak a fenntarthatóság mindhárom dimenziója felé történő egyidejű, pozitív irányú változását. Ezt látszik alátámasztani az is, hogy a HHÉ növelése csupán az olyan lehetőségek kihasználásával valósítható meg, mint:

- a termékek és szolgáltatások minőségének növelé$s e$, ami ezek magasabb áron történő értékesítését is jelenti (vagyis a gazdálkodók egyre inkább a feldolgozott (kész)termékek irányába fejlesztik gazdaságukat (ún. ,,a földtől az asztalig” rendszerek), s ez a piaci kiszolgáltatottságukat is csökkentheti a puszta alapanyag-elő́llítással szemben),

- a meglévő termelési struktúrák diverzifikációja a már meglévő vagy új, magasabb hozzáadott értéket előállító termékek felé (ami a minőségnövelő lehetőséghez hasonló típusú fejlesztéseket jelent, s gyakran a kettő együtt is jár!),

- környezetbarát termelési módok használata (ami egyidejűleg javítja a termékek minőségét, hozzájárul az élelmiszerbiztonság megerősítéséhez, amely az új ,európai mezőgazdaság” egyik prioritása, s kielégíti az egyre magasabb fogyasztói igényeket),

- a környezetvédelem és a tájképfenntartás szem előtt tartásával még több környezeti kulturális és társadalmi szolgáltatás előállítása a társadalom számára (ami egyben növeli a mezőgazdaság városi térségek által történő elismertségét), amely szolgáltatásokat ugyanakkor közvetlen támogatásokkal ellentételezni kell,

- nagyobb mértékü saját, a gazdaságban elóállitott input felhasználása (pl. mütrágya helyett istállótrágya, vásárolt elektromos áram helyett biogáz és megújuló (pl. szél)energia, ipari takarmánykeverék helyett saját takarmány). Az ilyen típusú inputkiváltásoknál növelhető a vidéki térségben a helyi erőforrások felhasználásának hatékonysága, munkahelyek teremthetők, csökkenthető a multinacionális cégek általi kiszolgáltatottság, valamint az így felhasznált inputok költségeit nem kell levonni a HHÉ kiszámításánál.

- új, külső inputokat nem, vagy csak kevésbé igénylö tevékenységek bevezetése (pl. saját feldolgozás, vendéglátás stb.), ami összhangban van a diverzifikációval, a minőségfejlesztéssel és a saját előállítású inputfelhasználás növelésével.

$\mathrm{Az}$ itt felsorolt lehetőségek közül bármelyiket (külön-külön vagy egyidejűleg többet) is választja az adott családi gazdaság, egyértelmúen növelni tudja az általa elő́llított hozzáadott értéket, ami egyidejűleg a 
fenntarthatóság felé történő elmozdulást, illetve a vidéki térségek fejlődéséhez (pl. foglalkoztatáshoz) való hozzájárulásának növelését is jelenti. Ez az az integrált hatás, ami a HHÉ egyszerűségét és lehetséges célszerűségét támasztja alá. A korábban bemutatott leíró jellegű mutatószámok nagyszáma, illetve számíthatósága nem teszi lehetővé a gazdaságokban végbemenő változások (pl. termékvertikumok kiépítése) gyors nyomon követését, illetve a szükséges adatok gazdaságonkénti begyüjtését. Ugyanakkor ahhoz, hogy a HHÉ mutató a gyakorlatban is felhasználásra kerüljön, meg kell változtatni mind a mezőgazdasági politikát, mind a támogatási rendszert, amelyek érdekeltté teszik a gazdálkodókat a felsorolt lehetőségek minél nagyobb mértékű kihasználásában. A HHÉ alapú támogatási rendszerben rövid idő alatt megvalósulhat a Közös Agrárpolitika reformjának azon célja, hogy a támogatások teljes mértékben elválasztásra kerüljenek a terméktípusoktól és -mennyiségektől (teljes „decoupling”), s a támogatás alapjául csupán egy ún. „termék független” paraméter szolgál. Vagyis a kiosztott támogatások úgy hoznak létre új termékpiacokat, hogy a tranzakciós költségek minimalizálásával még a fenntarthatóság társadalmi és környezeti dimenziói is érvényesülni tudnak.

Azonban ki kell hangsúlyozni, hogy a HHÉ pontos kiszámítása számos gyakorlati problémát vet fel. Általánosságban elmondható, hogy legpontosabban a családi gazdaságok szintjén lehet kiszámítani, mivel egy termelő gazdaság által előállított HHÉ megegyezik a gazdaság által megtermelt - és általában értékesített - termékek értékének, illetve a termeléshez szükséges vásárolt erőforrások és szolgáltatások öszszegének különbségével. Ebben az esetben a késztermékek értékesítésén túl a raktározott készleteket, illetve a készletjellegű anyagokat az adott térségben elérhető értékesítési átlagáron kell számításba venni. Ez a számítási mód szoros hasonlóságot mutat Kuhlmann (1981) számítási módszerével, aki könyvében rámutat a vállalkozások kétfajta eredményszámítási módszerének különbségeire. Vagyis arra, hogy a szokásos éves bevétel-kiadás kalkulációkban alkalmazott számítási mód nagymértékben különbözik az adott gazdasági évre számított költség-jövedelem kalkulációtól. Kuhlmann maga is kiemeli, míg az előbbi számítási módnál az állóeszközöket és a beruházásokat a bekerülési évben teljes költségen kell elszámolniuk, a költség-jövedelem kalkulációkban ezeket időarányosan, évekre felosztva kell szerepeltetniük a költségszámlákon. Hasonlóan más az elszámolási mód a már megtermelt, de még nem értékesített, valamint a már megvett, de még fel nem használt (készleten lévő) inputok elszámolásánál. A bevétel-kiadás kalkulációkban ezek a tételek teljes áron szerepelnek a bevételi és kiadási oldalon, míg a költség-jövedelem kalkulációkban csak az adott gazdasági évben ténylegesen felhasznált inputok kerülnek levonásra. Ez utóbbinál a már megtermelt, de még el nem adott (raktáron lévő) termékek részét képezik a vállalkozó jövedelemének, így azok megjelennek a jövedelemszámlán is, míg a bevétel-kiadási számlákon a készletek nem jelennek meg bevételként. Hasonlóan különbözik a készletértékelés módszertana is a kétfajta elszámoló rendszerben.

A HHÉ számításánál nagy problémát okoz a vállalkozói kivét, illetve a családtagok munkabérének és a hozzátartozó közterheknek a számbavétele. A hagyományos számítási logika szerint ezeket a tételeket levonják, viszont feltételezhető, hogy a vállalkozói kivéteket és munkabéreket a család későbbi vásárlásainál visszaforgatják vagy naturáliákban veszik ki, így a HHÉ számításánál mégsem kell levonandó tételekként szerepeltetni. A társadalombiztosítási befizetéseket azonban célszerű levonni, mert az állami újraelosztásban ezek nem biztos, hogy visszaforgatásra kerülnek! A korábbi példában vett gépjavításnál is jelentkezett a területi lehatárolás problémája, amely szorosan kapcsolódik a munkabérek elszámolásához. Gazdasági szinten minden (nem családtagnak) kifizetett munkabért levonnak, ugyanakkor települési vagy kistérségi szinten ezek a munkabérek „helyben maradnak”, így a családi gazdaságnál nagyobb léptékű elszámolásnál (pl. községi társulások, szövetkezetek támogatásánál) nem levonandó tételekként szerepelnek!

A HHÉ számításánál problémát jelenthet az ágazati szintű halmozódások kiszűrése. A halmozódás kiszűrésére csak a gazdaság szintjén elvégzett gyakorlati kipróbálás adhat megoldást, mivel a módszernek az alaplogika mentén történő ágazati szintű alkalmazása szinte használhatatlanná teszi a rendelkezésre álló adatok kezelését. Amennyiben például a tejágazatot veszszük alapul, egy liter tej elóállitásához felhasznált takarmányban már halmozottan jelen van a takarmány elöállitásakor felhasznált mütrágya mennyisége, vagy a vetéstől a takarmány kijuttatásáig felhasznált gépi szolgáltatások költsége, illetve a munkabérek és azok közterhei is. Mint arra korábban már rámutattam, a HHÉ pontos kimutatása elég nehéz, mert a csak vállalati szinten jelentkező kiadásokat a vállalkozás egészének szintjén állandó költségként kell elszámolni. Ez esetben egy módosított könyvelőprogrammal úgy kell feldolgozni minden ágazat számláit, hogy egyben a kimutatott hozzáadott értéket fajlagosan is kiszámítjuk. Egy családi vállalkozás esetében úgy kapjuk meg a vállalkozás HHÉ-ét, hogy a minden egyes 
ágazatra kiszámított bruttó vagy tevékenységi szintü hozzáadott értékek összegéből levonjuk a csak vállalati szinten jelentkező, külső erőforrások költségét. Ezzel az ún. bruttó hozzáadott értékekkel egyidejüleg megkapjuk, hogy az egyes ágazati tevékenységek mennyivel járulnak hozzá a gazdaság szintjén mérhető HHÉ-hez. Azonban az egyes ágazatokra vagy termékekre kiszámítani a HHÉ összegét szinte lehetetlen feladat, mert minden egyes tevékenységekhez kisebbnagyobb mértékben rendelhetô olyan vállalkozásszintű kiadás (pl. egy udvar felsepréséért fizetett munkabér), amely már csak közelítő eredményt ad, s ennek nagysága a tevékenységek számától, illetve az ágazatok sajátosságaitól függ. Ugyanakkor ki kell hangsúlyozni, hogy a módszer alkalmazhatóságának szempontjából nem elsőrendű követelmény a HHÉ pontos, termék vagy ágazati szintű meghatározása, inkább csak annak az elvnek a hangsúlyozása, hogy az egyes ágazatok hozzáadott értékének fokozatos növelésével egyfelől csökkenthetők a vállalkozás szintű állandó költségek, másfelől az egyre nagyobb ágazati HHÉkek az egész vállalkozást a fenntarthatóság irányába mozdítják el.

\section{A helyben hozzáadott érték mutatójának gyakorlati tapasztalatai}

A helyben hozzáadott érték mutató gyakorlati kipróbálását 2005-ben önkéntes alapon egy családi vállalkozásban ${ }^{3}$ végeztük el, amely rendelkezésre bocsátotta korábbi számviteli adatait. Ezekből igyekeztünk a lehető legrészletesebben elhatárolni a saját előállítású és a vásárolt (külső) inputokat és szolgáltatásokat. Mivel a 2004. évi számlák az érvényes előírások szerint lettek lekönyvelve, ki kell hangsúlyozni, hogy, a rendelkezésre álló adatok alapján a bemutatott HHÉ számítását csak megközelítőleg lehetetett elvégezni. A 2004. évi számlák alapján kijelenhető: a gyakorlati kipróbálásban a módosított számviteli szoftverek alkalmazása nélkül a HHÉ számítása a vállalkozások szintjén is körülményes. Ugyanakkor a számítások pontosíthatók, ha a vállalkozók a gazdasági év első napjától kezdve, a vizsgálati koncepcióban leírtak szerint könyvelik el a kiadásokat és a bevételeket.

A gyakorlati számításoknál valóban felmerült a korábban már érintett néhány probléma: vagyis a meglévő állattenyésztési és növénytermesztési ágazatok bevételeinek és kiadásainak egyértelmú elhatárolása, amely a 2004. évi adatok alapján a gyakorlatban sem

\footnotetext{
A szigorú anonimitás biztosítása érdekében sem nevet, sem semmilyen azonosítást elősegítő adatot itt közölni nem áll módomban!
}

volt lehetséges. A vizsgált Vállalkozás 28 helybeli munkaerőt foglalkoztat, akiknek a kifizetett munkabére a számításokban levonásra került, holott a dolgozók a saját élelmiszer-szükségleteik egy részét a Vállalkozástól veszik meg, így a munkabérek egy részét valójában „visszaforgatják”, vagyis egy rész megjelenik a bevételi oldalon is. Az elszámolásban a problémát ez a „visszaforgatási arány” meghatározása jelentette. A gyakorlati tapasztalatok alapján e konkrét példában ez 25-30\% körülire tehető.

Problémaként jelentkezett a számításokban a területi lehatárolás is. Az alapkoncepció ugyanis önálló (családi) gazdaságok gazdálkodásából indul ki, vagyis az egyes gazdaságok által végzett tevékenységek hozzáadott értékeinek összegzéséből és ez alapján méri e gazdálkodók tevékenységeinek hatékonyságát, illetve a tevékenységeknek a vidékfejlesztéshez való hozzájárulását. Ugyanakkor a mezőgazdasági termelésben sokkal általánosabb az a jelenség, hogy egy-egy ágazati tevékenység túlnyúlik az adott gazdaság határán, így ezt a problémát különös gonddal kell kezelni. Az alaplogika értelmében az adott ágazat gazdaságon kívül eső részét, mint levonandó tételt kell feltüntetni egy gazdaság elszámolásában, viszont a HHÉ elsődleges koncepciója az adott tevékenység (vagy egy teljes ágazat) vidékfejlesztéshez való hozzájárulásának mérésén alapul. Ebből a szemszögből azonban nem szabad azonosítani a gazdaságba kívülről bekerült, ám az adott térség számára helyben megtermelt értéket jelentő (pl. egy másik, helybéli vállalkozó által előállított, de helyi erőforrásra épülő) inputokat a tisztán külső inputokkal. Ilyen helyből bekerült inputoknak vehetők például azok az akácoszlopok is, amelyekből a gazdálkodó saját gépszínét építette fel, s amelyek nem saját elő́llításúak. Az alapképlet szerint ez levonandó tételként szerepel az adott gazdaságban, viszont mégis pozitív értéket (pl. egy újabb munkahelyet) képvisel az adott régió (vagy település) számára. E probléma feloldása a nehézségek ellenére nem lehetetlen.

A gyakorlati számítások alapján megállapítható, hogy térségi szinten számolva a HHÉ nagyságát, a vizsgált Vállalkozás által kifizetett munkabérek pozitívan járulnak hozzá a térség munkaerő megtartó képességének növeléséhez. Az egyre nagyobb aggregátumokkal (vállalkozás, település, kistérség, régió, ország) való számítások más és más HHÉ-et adnak, ugyanakkor általánosságban elmondható, hogy az országos szinten összegzett HHÉ a teljes mezőgazdaság nettó nemzeti termékével lesz egyenlő. Kormányzati oldalról nézve ez azt jelenti, hogy a HHÉ alapú támogatási rendszer bevezetése egyfelől növeli a hazai mezőgazdaság versenyképességét, másfelől közelebb vi- 
szi az országot a fenntartható mezőgazdaság (és életképes vidék) megvalósításához. A HHÉ alapú támogatási rendszerben könnyen meghatározható a környezeti előnyökért adott támogatások mellett a környezeti károkozások nagysága is. A különböző Jó Mezőgazdálkodási Gyakorlatoktól való eltérésnél életbe kellene léptetni az ún. „szennyező fizet” elvet, amely konkrét kifizetést (bírságot) jelent a vállalkozó számára, amelynek összege levonásra kerül az általa előállított HHÉ összegéből. Az így módosuló HHÉ után csupán csökkentett támogatást kapna, amely szintén ösztönzőleg hat rá, hogy átalakítsa mezőgazdálkodási gyakorlatát.

A módszer gyakorlati sikerességét azonban a több gazdasági évet felölelő kipróbálás tudná visszaigazolni, ám már a gazdaságok tervezésénél is figyelembe kell(ene) venni a mutató használhatóságát. Az általam bemutatott integrált mutató egyik célja az, hogy támpontot nyújtson a jövőben megvalósuló, vagy már működő, de tevékenységi körét diverzifikáló gazdaságok megtervezéséhez is. Ehhez viszont az szükséges, hogy a már leírt szempontokat integráljuk a hagyományos üzemtervezés gyakorlatába. Mindezek alapján az elkövetkező kutatásokban nagy hangsúlyt fektetek ennek a problémakörnek a vizsgálatára is. A bonyolult termelési folyamatokat modellező, de számítási módszereiben lineáris összefüggéseket feltételező üzemtervekben a bruttó bevételek (vagyis a TÉ), valamint a felhasznált inputok és gépi szolgáltatások összegének különbözete adja az egyes ágazatok fedezeti összegét. Ezek az egyszerűsítő számítások adják a végső eredmény kimutatást, ami alapján nagyjából becsülhetők az adott gazdaság rövid távú (ált. 3-5 éves) gazdasági mutatói. Itt kell kihangsúlyozni, hogy ez a számítási mód az angol fedezeti összeg számítás gyakorlatára épül, amely nem veszi figyelembe többek között az adott ágazatban szereplő munkaerő költségeit, illetve az általános költségek között tünteti fel. Ugyanakkor az általános „farm management” szakirodalomban használt eredménykimutatás nagyon közel áll a HHÉ számítási módszerhez, így a probléma számítógépes alkalmazásának kidolgozása az elkövetkező időszak kutatási feladatává válik. A HHÉ számítási módszerének kidolgozásával egy időben elindult egy saját fejlesztésű tervezőszoftver rendszerfejlesztése is, amely felépítésében megpróbálja integrálni az imént leírt elveket és a gyakorlati tapasztalatokat is.

\section{Felhasznált irodalom}

Laki, G. (2002): Added value as the basis of sustainable agriculture's subsidy system. In: (Eds. Trebicky, V. - Novak, J.) "Rio+10 Transition from Centrally Planned Economy to Sustainable Society? (Visegrad Agenda 21)", Conference Proceedings, Institute for Environmental Policy, Prague, 2002, 49. p.

Laki, G. - Szakál, F. (2002): Added Value as a key indicator for sustainable agriculture. A mezőgazdasági termelés és erőforrás-hasznosítás ökonómiája című VIII. Nemzetközi Agrárökonómiai Tudományos Napok, SZIE Gazdálkodási és Mezőgazdasági Főiskolai Kar, Gyöngyös, 6 p.

Laki, G. (2003): A fenntartható mezőgazdaság hatékonyságának mérési problémái. In: „EU Konform mezőgazdaság és élelmiszerbiztonság” (Szerk.: Dimény, J., Pepó, P. et al.), Konferencia kiadvány, I. kötet, Gödöllő, 421-427 p.

Módos, Gy. (2001): A diverzifikáció szerepe a vidékfejlesztésben. In: „Vidékfejlesztés-Környezetgazdálkodás-Mezőgazdaság” XLIII. Georgikon Napok c. tudományos konferencia kiadványa, I. kötet, (Szerk.: Palkovics, M., Kondorossyné Varga, E.), Keszthely, 99-102. p.

Szakál, F. (1992): Gazdasági rendszerelmélet, egyetemi jegyzet, Gödöllő, p. 85

Winter, M. - Turner, M. et al. (2002): Farm Diversification Activities: Benchmarking study, Final report to DEFRA, University of Exeter, London, England, 58 p. 